\title{
Development and Validation of Digital Literacy Scale (DLS) and its Implication for Higher Education
}

\author{
Hina Amin \\ Virtual University of Pakistan, \\ hina.amin@vu.edu.pk, \\ Muhammad Abid Malik \\ m_abidmalik7@yahoo.com \\ Bulent Akkaya \\ Manisa Celal Bayar University, Manisa, Turkey
}

\begin{abstract}
The study aimes to develop and validate Digital Literacy Scale (DLS) based on Chen's (2015) theoretical framework which includes nine dimensions: communication, collaboration, critical thinking, creativity, citizenship, character, curation, copyright, and connectedness. A question pool consisting of 62 items based on the nine dimensions of digital literacy was generated on a 5-point Likert-type scale. Content validity of the question pool was sought from experts in terms of clarity of items, language understanding, and relevance. SPSS and AMOS were used for statistical analysis. Using a sample of 349 university students, Exploratory Factor Analysis was employed for reliability analysis, construct validation, and factor structure of the scale. EFA confirms the nine dimensions; however, some items were deleted during this process. Finally, Confirmatory Factor Analysis was employed to check the reliability and validity of the factor structure by using a second sample $(\mathrm{n}=442)$. CFA showed that all the values were within the acceptable range (Kaiser-Meyer-Olkin 0.886, the total variance explained $62.87 \%$, Cronbach Alpha 0.894, and the goodness of fit 0.924). Thus a standardized DLS consisting of 36 items and 9 factors (communication, copyright, critical thinking, character, citizenship, curation, connectedness, creativity, and collaboration) was finalized. DLS is a psychometrically sound, reliable, and valid measurement tool that can be used to measure digital literacy.
\end{abstract}

Keywords: Digital literacy, online education, information and communication technology (ICT), 9 C's of digital literacy, university students

\section{Introduction}

Advances in information and communication technologies (ICTs) over the last two decades have connected people across the globe through the internet, digital mediums, and online platforms (Spires et al, 2019). To communicate effectively and thrive in this digital world, one not only needs to have knowledge about these tools and platforms; but also the ability and skills to use them purposefully. ICT and digital technologies have also transformed the ways of communications and learning for teachers and students alike. Teachers and students are using these tools in innovative and creative ways for improved learning outcomes (Literat \& Glaveanu, 
2018). Even students of distance education have acknowledged that the use of online and digital technology can significantly improve their learning process (Noreen \& Malik, 2020).

Nowadays, students are using different digital technologies for a diverse range of activities i.e. sending and reading emails, reading e-books and online content, participating in online academic discussions, and accessing and using learning management systems (Kim \& Choi, 2018). Nordin et al. (2016) reported a study conducted in 2012 in the United States of America about higher education students to analyze their digital dependence $(\mathrm{N}=500)$. It reported that $91 \%$ of the students used email as one of the main means of communication with their professors, $74 \%$ used digital content, $70 \%$ used tablets to take notes in classrooms, and $73 \%$ of the sampled students in the survey said that they could not study without digital technologies (Course smart, 2011). Similarly, Amin and Mirza (2020) found that students and teachers in online education were more proficient in advance searching and using diverse e-tools for collaboration and data processing. The frequent use and exposure to the digital world are also shaping the students' attitudes, mindset, and experiences (Henderson et al., 2015). Gruszczynska, et al. (2013) also highlighted the importance of technological transformations and their impact on academic, cultural, social, and economic life. These changes are also greatly influencing the teaching-learning process, academic discourse, and research culture across educational institutes.

In the beginning, the term computer literacy was used which meant one's ability to use computers effectively for the given purpose (Sweaney et al., 2001). This is perhaps due to the limited awareness and access of the internet and digital medium to the common public. With the expansion of the internet and other online and digital platforms, the term digital literacy has started to replace it in recent times. Digital literacy includes one's ability to use e-resources, digital media, and online platforms in an open and flexible environment. With the passage of time, its parameters have been expanded and social capital has also been added to it. As a result, digital literacy is no longer limited to the ability to use computers, digital platforms, and online media effectively; but also in a socially and culturally responsible way (Adeoye \& Adeoye, 2017; Chan et al., 2017).

\subsection{Rationale of the Study}

Previous studies pointed out that although students are becoming technologically more skilled, still not all of them enter higher education institutions with the same level of digital and technological competencies (Inskip, 2014). Some may have the required level of knowledge and skills, while others may not be equipped with these skills which are now considered essential for students to cope in the multicultural and complex environment. To investigate this properly, one needs a standardized scale to measure the digital literacy of students. Although some scales have already been developed to measure digital literacy based on some other frameworks, the framework presented by Chen (2015) appears to be one of the most comprehensive ones for digital literacy. The dimensions in it (called $9 \mathrm{C}$ 's) not only focus on digital abilities and competencies, but also its social and cultural aspects. Although this framework was originally developed for American K-12 students, its dimensions are also required and applicable not only for students at other levels, but also to the general public. As a result, it was decided to develop and validate a digital literacy scale based on 9 C's. 


\subsection{Objective of the Study}

The objective of the study is to develop and validate a standardized scale to measure digital literacy skills based on the 9 C's.

\section{Review of the Related Literature}

The literature review was divided into three main parts: evolution of the term and concept of digital literacy, theoretical frameworks of digital literacy construct, and $9 \mathrm{C}$ 's of digital literacy.

\subsection{Digital Literacy: Historical Development of the Term and the Concept}

Literacy (reading and writing) has always been one of the most important skills for human beings. With the advent of computers and their involvement in everyday life, computer literacy (the ability to use computers effectively for the given task) also gained prominence. Later, as the internet, ICT, online platforms, and digital media became common; the term computer literacy was widely replaced with digital literacy.

Cam and Kiyici (2017) said that in the context of the $21^{\text {st }}$ century, the term literacy had a different understanding. They further added that "digital literacy is the skill acquisition process" which became more relevant and productive in the current digital world (p. 30). It has been broadly linked with software literacy, information literacy, visual literacy, and computer literacy. There have been various definitions and parameters of digital literacy with substantial similarities and overlapping (Gillen \& Barton, 2009). Sometimes, the use of different terminologies and factors also causes confusion (Abbas et al. 2019).

Most of the earlier definitions of digital literacy focused on functional skills or the ability to use, communicate and create using digital tools and platforms. Glister (1997) defined digital literacy as "ability to understand and use information in multiple formats from a wide range of sources when it is presented via computers (p.1). American Library Association (2012) defined digital literacy as "the ability to use information and communication technologies to find, evaluate, create, and communicate information, requiring both cognitive and technical skills". Greene et al. (2014) said that one must be able to search, manage, scrutinize and integrate digital information in order to be considered digitally literate. Some researchers said that digital literacy equips individuals with the necessary skills to read text from screens and interpret the meaning of digital words, symbols, and graphical expressions (Kress, 2003; Gee, 2003). Despite covering a wide area of skills and competencies about digital and online tools, none of them talk about social, moral, or ethical aspects of digital literacy.

Later versions of digital literacy, started to incorporate social and ethical aspects into it. Chan et al. (2017) defined digital literacy as an umbrella framework to develop knowledge, skills, and ethics in the digital world. Adeoye and Adeoye (2017) further elaborated it by saying that digital literacy was much more than having access to the digital world and being able to use it. It was about collaborating, staying safe, communicating effectively, and being responsible towards others while interacting online.

Digital literacy is as much about social, cultural understanding, and awareness to use digital tools and platforms in a responsible way. It is about knowing and understanding when, where, and how to use digital technologies appropriately. Due to the availability and easy access to these digital mediums, and the fact that the person behind those devices and platforms is 
invisible; the ethical and social aspects of digital literacy become even more important. Spires et al. (2019) stated that although digital technologies were extensively used in the recent decade, and considered one of the essential competencies of $21^{\text {st }}$-century skills; there was a growing concern amongst academia towards its safe and socially responsible use.

Digital literacy is a highly important concept in the online world as it not only demands the proficient use of technology, but also its ethical and responsible use which ultimately leads towards becoming a responsible citizen. Children and young people are more active users of new technologies, hence at greater risk of negativity and misdirection in the online world (Burnett \& Merchant, 2011). As a result, the role of researchers and educationists becomes more important to preach and promote digital literacy with its techno-social usage (Gruszczynska, Merchant, \& Pountney, 2013).

\subsection{Theoretical Frameworks of Digital Literacy Construct}

A systematic review of the literature reveals that there have been multiple frameworks for digital literacy. Despite some similarities, all of them have their distinctive features, strengths, and limitations. Some of them focus on the technical competencies such as computer and technical literacy only (Martin, 2006) while others also talk about social and cultural aspects (Ng, 2012; Chen, 2015).

Sifting through the literature, the researchers found seven different frameworks for digital literacy that have been presented over the years (Table i). Martin (2006) presented a framework for digital literacy with three levels. All of them focused on its knowledge, use, and creation of new knowledge with it. None of them focused on social, ethical, moral, or citizenship aspects.

Table i: Digital Literacy Frameworks*

\begin{tabular}{|c|c|c|c|}
\hline Author(s) & Factors & Model & Focus \\
\hline \multirow{5}{*}{$\begin{array}{l}\text { Eshet-Alkalai, } \\
2004\end{array}$} & Five & Photo-visual literacy & i) the art of reading visual representations \\
\hline & factors & reproduction literacy & ii) the art of creative recycling of existing materials \\
\hline & & information literacy & iii) hypermedia and non-linear thinking \\
\hline & & branching literacy & iv) the art of skepticism \\
\hline & & $\begin{array}{l}\text { socio-emotional } \\
\text { literacy }\end{array}$ & v) socio-emotional literacy \\
\hline \multirow[t]{3}{*}{ Martin, 2006} & Three levels & digital competence & i) know-how \\
\hline & & digital usage & ii) applications of digital competence \\
\hline & & digital transformation & iii) creation of new knowledge \\
\hline \multirow[t]{4}{*}{ Bawden, 2008} & Four & & i) underpinnings \\
\hline & Component & - & ii) background knowledge \\
\hline & & & iii) central competencies \\
\hline & & & iv) attitudes and perspectives \\
\hline
\end{tabular}




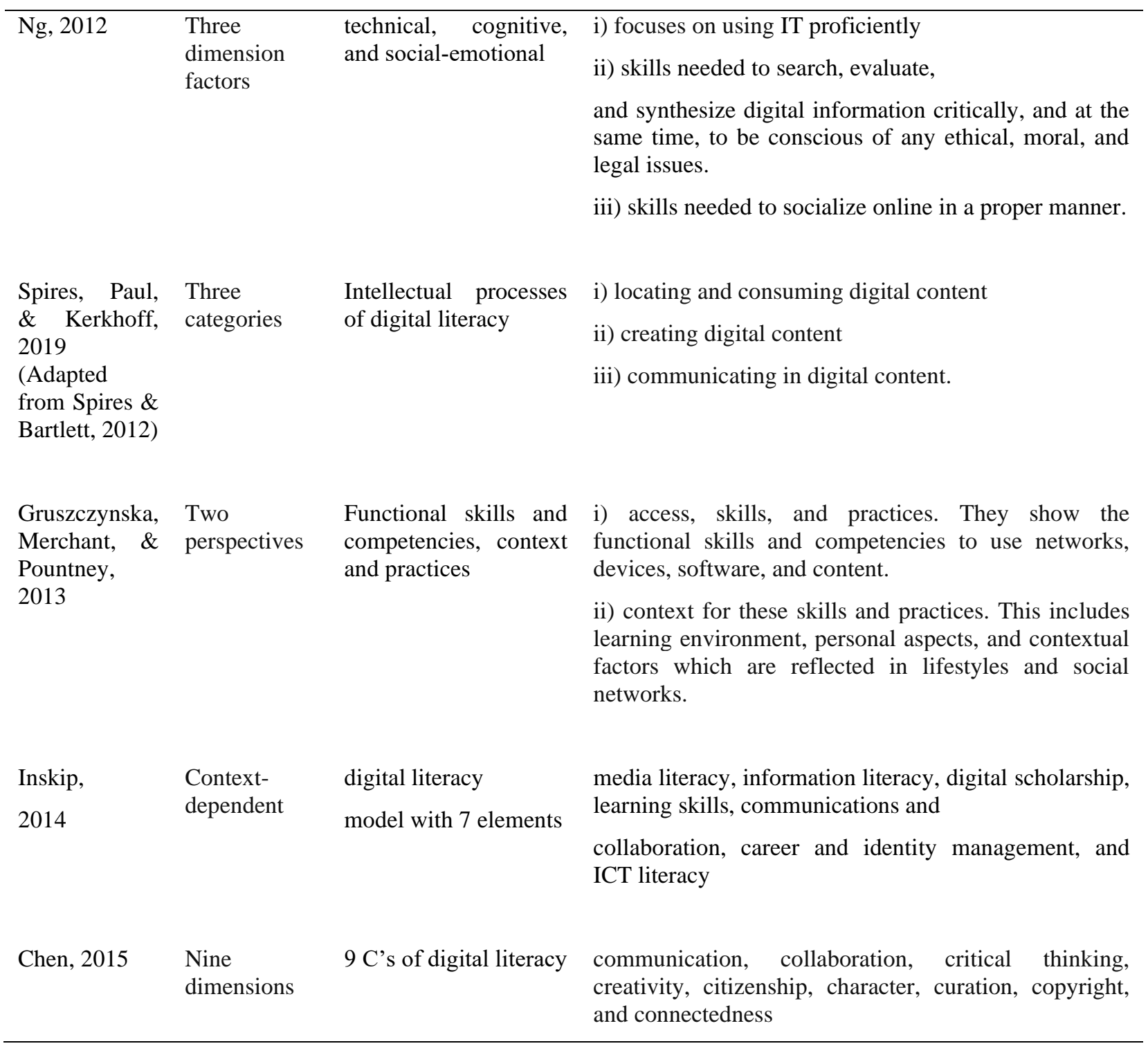

* Table prepared by the authors based on the previous studies

The framework proposed by Eshet-Alkalai (2004) had five factors. Although, it also included socio-emotional literacy; it was dominated by the ability to think, use, communicate and create. In 2012, Ng presented another framework with three dimensions. It also included the socio-emotional aspect as one of the three dimensions. Bawden (2008)'s framework had four components. Although attitudes and perspectives were one of those dimensions, it was still dominated by the understanding, background knowledge, and ability to use digital tools effectively. Spires et al. (2019) presented a framework that had been adapted from Spires and Bartlett (2012). It divided digital literacy into three categories: searching and using, creating, and communicating using digital tools and contents (Figure i). This framework focuses on functional skills of digital literacy only. 
Figure i: Intellectual processes of Digital Literacy

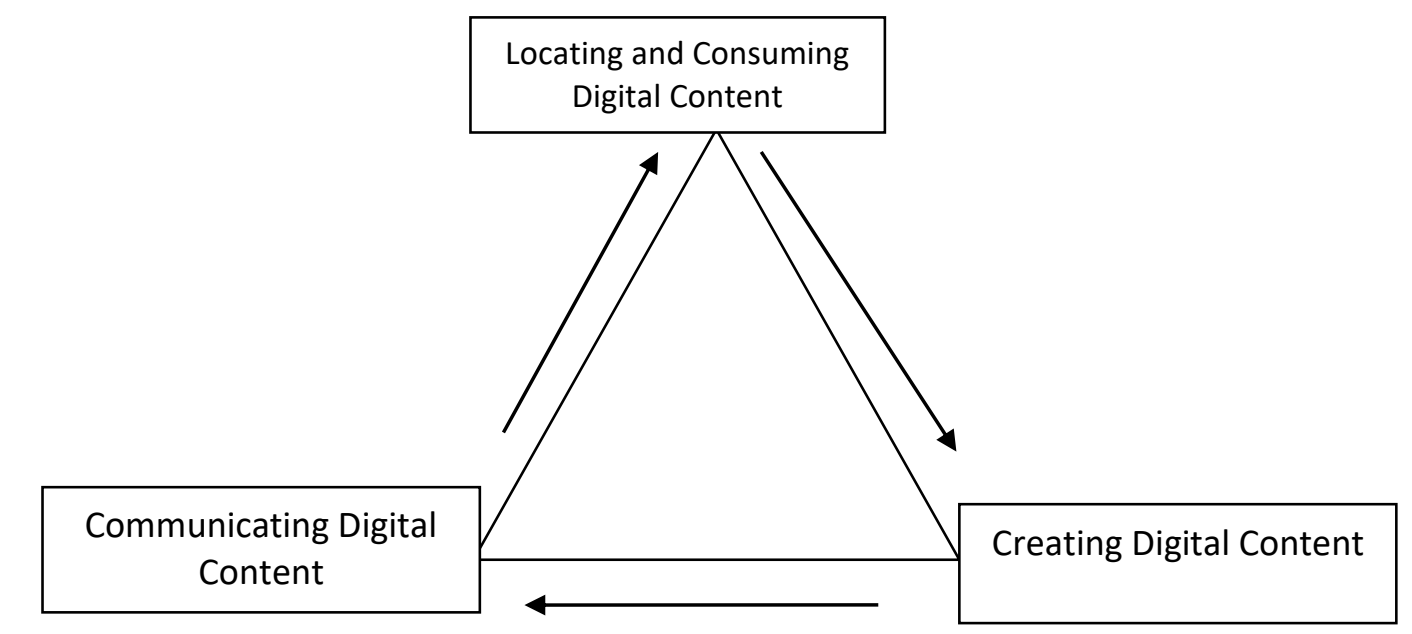

Intellectual processes of Digital Literacy Spires, Paul and Kerkhoff, 2019

Frameworks originally developed and presented after 2012 started to pay more attention to social, psychological, moral, and ethical aspects of digital literacy. Based on JISC (2010) framework; Gruszczynska, Merchant and Pountney (2013) described the anatomy of digital literacy from two different, but related perspectives. The first one is about access, skills, and practices. These skills show the functional skills and competencies to use networks, devices, software, and content. The second perspective refers to the context for these skills and practices. This includes the learning environment, personal aspects, and contextual factors. It is reflected in lifestyles and social networks. Inskip (2014) presented a context-dependent framework that also focused on collaboration and identity management.

In 2015, Chen presented another framework for digital literacy with 9 C's (communication, collaboration, critical thinking, creativity, citizenship, character, curation, copyright, and connectedness). This framework appears to be the most comprehensive to date with a focus on almost all of the skills that may be required to not only use digital tools and platforms effectively, but also in a responsible and socially beneficial way. As a result, this study decided to develop and validate a digital literacy scale based on 9C's.

\subsection{C's of Digital Literacy}

Despite many similarities and overlapping, most of these frameworks have their own distinctive strengths and limitations. Computer, digital and technical competencies are emphasized in all of them; but when it comes to social, psychological, moral, ethical values and citizenship, most emphasize some elements or the other, thus leaving some gap. In 2015, Chen presented a framework for digital literacy based on 9 C's. This framework consists of almost all the important components of the previous frameworks, along with other additional dimensions. Those 9 C's for digital literacy are communication, collaboration, critical thinking, creativity, citizenship, character, curation, copyright, and connectedness. Gaining these competencies may not only help a person to use the online and digital platforms effectively, but also to become a responsible and socially beneficial citizen in the virtual world. 
Figure ii: 9 C's of Digital Literacy by Chen (2015) (Adapted)

\begin{tabular}{|c|c|c|}
\hline $\begin{array}{c}\text { Communication } \\
\text { online reading, writing, } \\
\text { speaking and listening } \\
\text { skills }\end{array}$ & $\begin{array}{l}\text { Collaboration } \\
\text { how to work with everyone } \\
\text { online, not just with their } \\
\text { friends. }\end{array}$ & $\begin{array}{l}\text { Critical Thinking } \\
\text { to solve problems, analyze } \\
\text { deeply, and question } \\
\text { frequently through digital }\end{array}$ \\
\hline $\begin{array}{c}\text { Creativity } \\
\text { to become online content } \\
\text { creators, not just } \\
\text { consumers of knowledge. }\end{array}$ & $\begin{array}{l}\text { Citizenship } \\
\text { to use technology } \\
\text { responsibly and legally. }\end{array}$ & $\begin{array}{c}\text { Character } \\
\text { to be active advocates of } \\
\text { online ethical practices even if } \\
\text { not legally required. }\end{array}$ \\
\hline $\begin{array}{l}\text { Curation } \\
\text { to understand digital } \\
\text { research skills and how to } \\
\text { analyze the credibility of } \\
\text { web content. }\end{array}$ & $\begin{array}{c}\text { Copyright } \\
\text { Understanding and } \\
\text { following online and } \\
\text { digital copyright laws. }\end{array}$ & $\begin{array}{l}\text { to become active participants } \\
\text { and contribute to the global } \\
\text { community by helping the } \\
\text { people online. }\end{array}$ \\
\hline
\end{tabular}

\section{Methodology}

\subsection{Theoretical Foundation, Method and Tool}

The process of scale development and validation started by developing a question pool based on Chen (2015) 9 C's. Though observational studies have proven to be more useful for offering a practical view of the digital skills for scale development, their cost and time are indeed a powerful limitation (van Deursen et al., 2012). On the other hand, with self-reported questionnaires, one can present a large number of questions about a wide range of factors to a large sample in a short time. Scoring is also simple, fast, and cost-effective. It is important to note that there is no agreement regarding the use of self-reporting measures. Some of the previous studies have shown that self-ratings tend to be overly positive (Kuhlemeier \& Hemker, 2007).

The researchers extensively searched for the meanings and terms of each of the nine dimensions multiple times. For the nine dimensions of digital literacy (9 C's), 62 items were originally developed which were measured on a 5-point Likert-type scale (1 strongly disagree to 5 strongly agree) to develop the Digital Literacy Scale (DLS).

\subsection{Sample of the Study}

The sample consisted of university students belonging to five different universities in Pakistan. The reason behind selecting university students was that they are amongst those demographic groups who use computers, the internet, and digital media most frequently. Their age ranged from 18 to 32 years. The analyses were conducted on two different randomly selected samples with volunteer participation. There have been studies such as Bryman and Cramer (2001), Hair et al. (2006), Croasmun (2011), and Comrey and Lee (2013) investigating the optimal sample size for scale development. In this study, guidelines suggested by Bryman and Cramer's (2001) have been followed. According to them, the sample should be at least five times more than the items. The researchers tried to gather a sample size larger than the minimum required size. 
The first set of data consisted of the first sample $(n=349)$ which was used to test validity and reliability by employing exploratory factor analysis. The second sample $(n=442)$ was employed to retest and verify the factor structure.

\section{Data Findings and Analysis (Scale Development)}

Having established the framework, the researchers followed three stages to develop the scale. Hinkin (1998) suggests that the theoretical basis or the description should provide sufficient information for the initial collection and development of items for scale development. Based on that, 62 items were developed initially. Following three steps were taken for scale development, refinement, and validation.

\subsection{Step 1: Item Generation, Purification and Content Validation}

The expressions based on the 9 C's of Digital Literacy by Chen (2015) were deeply studied, analysed, and converted into items. At the first stage, researchers prepared an initial pool of 62 items after understanding each dimension of digital literacy. Followed by generating the statements and content validity. The researchers made use of the technique suggested by Hinkin and Tracey (1999) and Worthington and Whittaker (2006) for this purpose. The scale was sent to five experts in the education and scale development domain. Those experts belonged to three different universities, and two different countries. They had 6 to 16 years of experience in research.

The items were reviewed to remove those which were confusing, overlapping, or incorrect. This study retained only items that four experts evaluated as "clearly representative" and the fifth expert as "somewhat representative". This process eliminated 6 items, resulting in a scale with 56 items. Through this step; the content, language, and structure of the scale were validated.

\subsection{Step 2: Reliability Assessment and Construct Validation (EFA and CFA)}

To explore the factor structure and correlation behaviour of DLS; data were collected from 349 university students. Most of them (36.7\%) were 21-24 years old. 33.7\% were male and others were female. The majority of the participants $(69.3 \%)$ said that they learned computer and digital literacy skills by themselves. $20.3 \%$ of them stated that they would spend five to ten hours a week on the internet.

First of all, digital literacy scale items were examined by using exploratory factor analysis (EFA). Bryman and Cramer (2001) and Hair et al. (2006) recommend minimum criteria for observations acceptable for EFA as five times the number of items in the scale. The item to response ratio for the current EFA was more than six times the number of items in the scale (349/56 6.2). Therefore, the sample was adequate for carrying out EFA.

Bartlett's test of Sphericity and, Kaiser-Meyer-Olkin (KMO) test for sample adequacy were applied in SPSS (Lau \& Yuen, 2914) to see the factorability of the data. According to the literature, a value above 0.5 indicates the sample size adequacy (Kaiser, 1974; Sharma, 1996). The KMO measure of sampling adequacy yielded a value of 0.886 , indicating good sampling adequacy. The test of Sphericity was significant $(\chi 2(595)=5054.693, p<.001)$, showing that the sample was appropriate for structure detection. The results are presented in Table ii. 
Table ii. Results of KMO and Bartlett's Tests

\begin{tabular}{|c|c|c|}
\hline \multicolumn{3}{|l|}{ KMO and Bartlett's Tests } \\
\hline \multicolumn{2}{|c|}{ Kaiser-Meyer-Olkin Measure of Sampling Adequacy. } & .886 \\
\hline \multirow[t]{3}{*}{ Bartlett's Test of Sphericity } & Approx. Chi-Square & 5054.693 \\
\hline & df & 595 \\
\hline & Sig. & .000 \\
\hline
\end{tabular}

Kaiser (1974) recommends that the Eigen values below 1.0 are indicative of possibly unstable factors. By applying the Kaiser criteria, $62.87 \%$ of the total variance was explained by nine factors, and the factors theoretically corresponded to the digital literacy construct. Table iii presents the total variance explained and the number of the factors.

Table iii: Total Variance Explained

\begin{tabular}{|c|c|c|c|c|c|c|c|c|c|}
\hline \multicolumn{10}{|c|}{ Total Variance Explained } \\
\hline \multirow[b]{2}{*}{ Component } & \multicolumn{3}{|c|}{ Initial Eigenvalues } & \multicolumn{2}{|c|}{$\begin{array}{l}\text { Extraction } \\
\text { Loadings }\end{array}$} & \multicolumn{3}{|c|}{$\begin{array}{c}\text { SquaredRotation } \\
\text { Loadings }\end{array}$} & \multirow{2}{*}{$\begin{array}{l}\text { of Squared } \\
\text { ofCumulative } \\
\%\end{array}$} \\
\hline & Total & $\begin{array}{l}\% \\
\text { Variance }\end{array}$ & $\begin{array}{l}\text { ofCumulative } \\
\%\end{array}$ & Total & $\begin{array}{l}\% \\
\text { Variance }\end{array}$ & $\begin{array}{l}\text { ofCumulative } \\
\%\end{array}$ & Total & $\begin{array}{l}\% \\
\text { Variance }\end{array}$ & \\
\hline 1 & 8.853 & 25.295 & 25.295 & 8.853 & 25.295 & 25.295 & 5.057 & 14.448 & 14.448 \\
\hline 2 & 3.726 & 10.646 & 35.941 & 3.726 & 10.646 & 35.941 & 2.803 & 8.009 & 22.457 \\
\hline 3 & 1.770 & 5.057 & 40.998 & 1.770 & 5.057 & 40.998 & 2.695 & 7.699 & 30.156 \\
\hline 4 & 1.629 & 4.656 & 45.653 & 1.629 & 4.656 & 45.653 & 2.519 & 7.197 & 37.352 \\
\hline 5 & 1.529 & 4.367 & 50.021 & 1.529 & 4.367 & 50.021 & 2.366 & 6.760 & 44.112 \\
\hline 6 & 1.300 & 3.714 & 53.735 & 1.300 & 3.714 & 53.735 & 2.071 & 5.916 & 50.028 \\
\hline 7 & 1.139 & 3.254 & 56.990 & 1.139 & 3.254 & 56.990 & 1.612 & 4.605 & 54.633 \\
\hline 8 & 1.057 & 3.021 & 60.011 & 1.057 & 3.021 & 60.011 & 1.531 & 4.375 & 59.007 \\
\hline 9 & 1.001 & 2.861 & 62.871 & 1.001 & 2.861 & 62.871 & 1.352 & 3.864 & 62.871 \\
\hline
\end{tabular}

Extraction Method: Principal Component Analysis.

As factors correlate theoretically, the researchers used Varimax rotation (a type of orthogonal rotation) for analysis. The factor loading values should be greater than 0.30 (the lowest acceptable limit). According to Büyüköztürk (2009), items with less than this limit or loading in more than one factor should be removed from the scale one by one. Whereas, Worthington and Whittaker (2006) argued that the researchers must set their minimum values of factor loadings as high as possible so that they result in fewer cross-loading. In this study, the researchers set the minimum factor loading at 0.30. Sixteen items (item 9, 15, 21, 25, 26, 28, 30, $33,35,36,41,44,49,50,55$ and 56) which had a factor loading values less than 0.30 or loading in more than one factor were removed. Factor structure was again checked by re-analysis. Then principal component analysis (PCA) was carried out. Through this process, nine factors and 36 items were extracted.

Table iv presents the items and the factors which are in the acceptable range for factor loading. 
Table iv. The Results of EFA for DLS (Digital Literacy Scale)

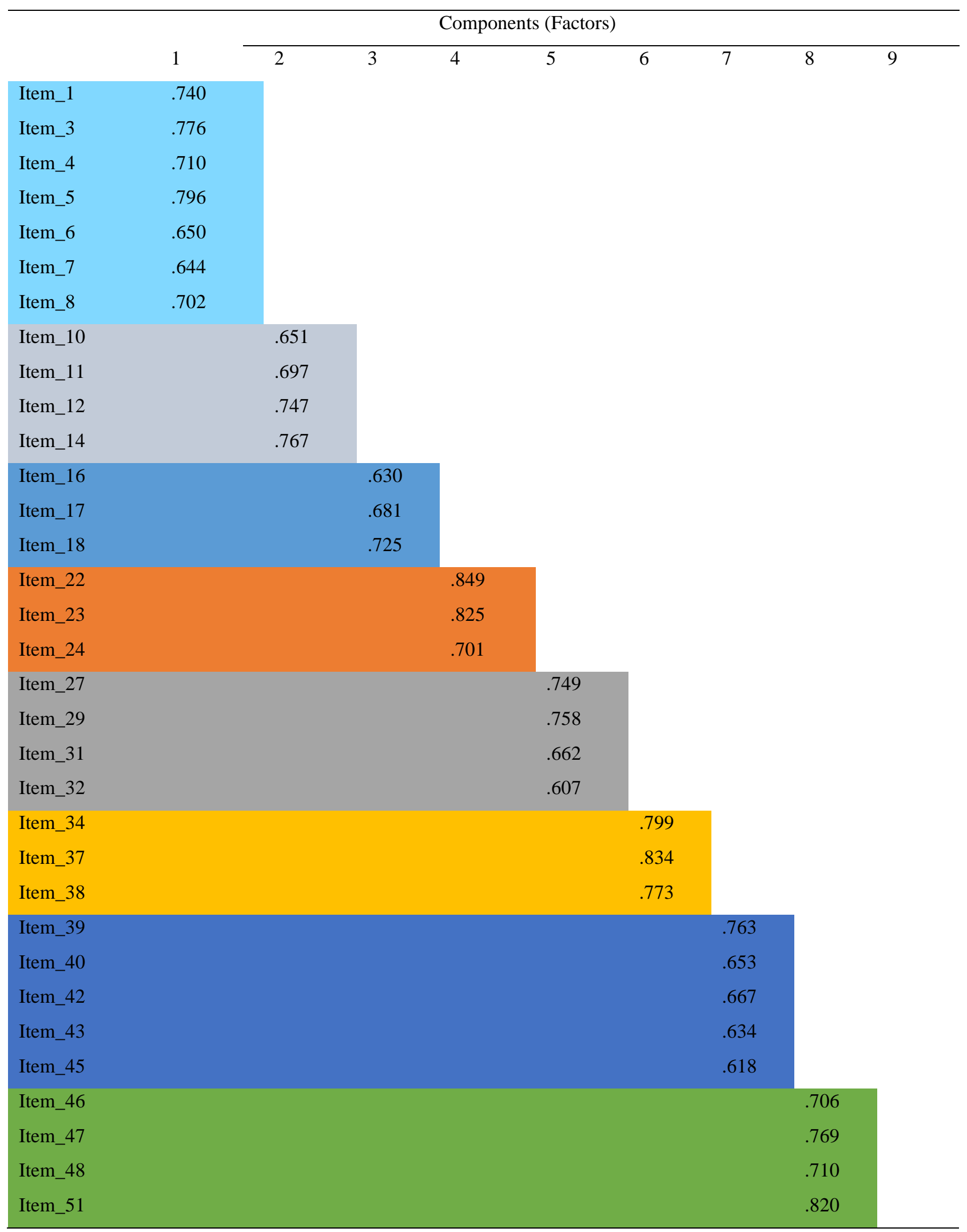




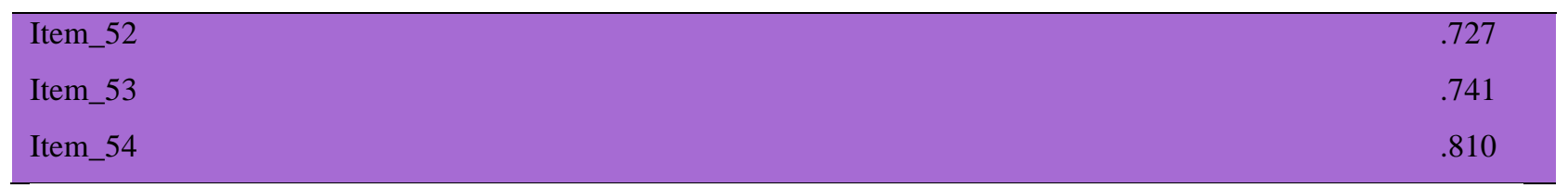

Extraction Method: Principal Component Analysis. Rotation Method: Varimax with Kaiser Normalization. a. Rotation converged in 7 iterations.

Capturing the essence of the factors, they were named after 9 C's of Digital Literacy by Chen (2015): Factor 1, Communication; Factor 2, Copyright; Factor 3, Critical Thinking; Factor 4, Character; Factor 5, Citizenship; Factor 6, Curation; Factor 7, Connectedness; Factor 8, Creativity; and Factor 9, Collaboration. In this way, the empirically extracted nine factors displayed congruence with the theoretical conceptualization of the construct of digital literacy. After extraction of items under each factor, reliability of each factor was found. According to DeVellis (2012), Cronbach's alpha value above 0.7 is considered acceptable in social sciences.

Table v shows the Cronbach's alpha value for each factor, and also for overall scale.

Table v. Factor Names and Reliability

\begin{tabular}{|c|c|c|c|}
\hline $\begin{array}{l}\text { S. } \\
\text { No. }\end{array}$ & Factor Name & $\begin{array}{l}\text { No. of } \\
\text { Items }\end{array}$ & $\begin{array}{l}\text { Cronbach's } \\
\text { Alpha }\end{array}$ \\
\hline 1 & Communication & 7 & 0.815 \\
\hline 2 & Copyright & 4 & 0.853 \\
\hline 3 & Critical Thinking & 3 & 0.832 \\
\hline 4 & Character & 3 & 0.831 \\
\hline 5 & Citizenship & 4 & 0.857 \\
\hline 6 & Curation & 3 & 0.847 \\
\hline 7 & Connectedness & 5 & 0.885 \\
\hline 8 & Creativity & 4 & 0.857 \\
\hline 9 & Collaboration & 3 & 0.878 \\
\hline Total & DLS & 36 & $\mathbf{0 . 8 9 4}$ \\
\hline
\end{tabular}

After this step, the researchers extracted the factor structure of the DLS by EFA and then confirmed the factor structure by carrying out a confirmatory factor analysis (CFA). This process led to the final development of the scale for measuring digital literacy skills based on $9 \mathrm{C}$ 's. As EFA explores the factor structure about how variables relate within a group, CFA results by using AMOS confirm the factor structure extracted from the EFA (Nunnally \& Bernstein, 1994). Figure iii presents the results of CFA. 
Figure iii. Result of CFA (Sample 1)

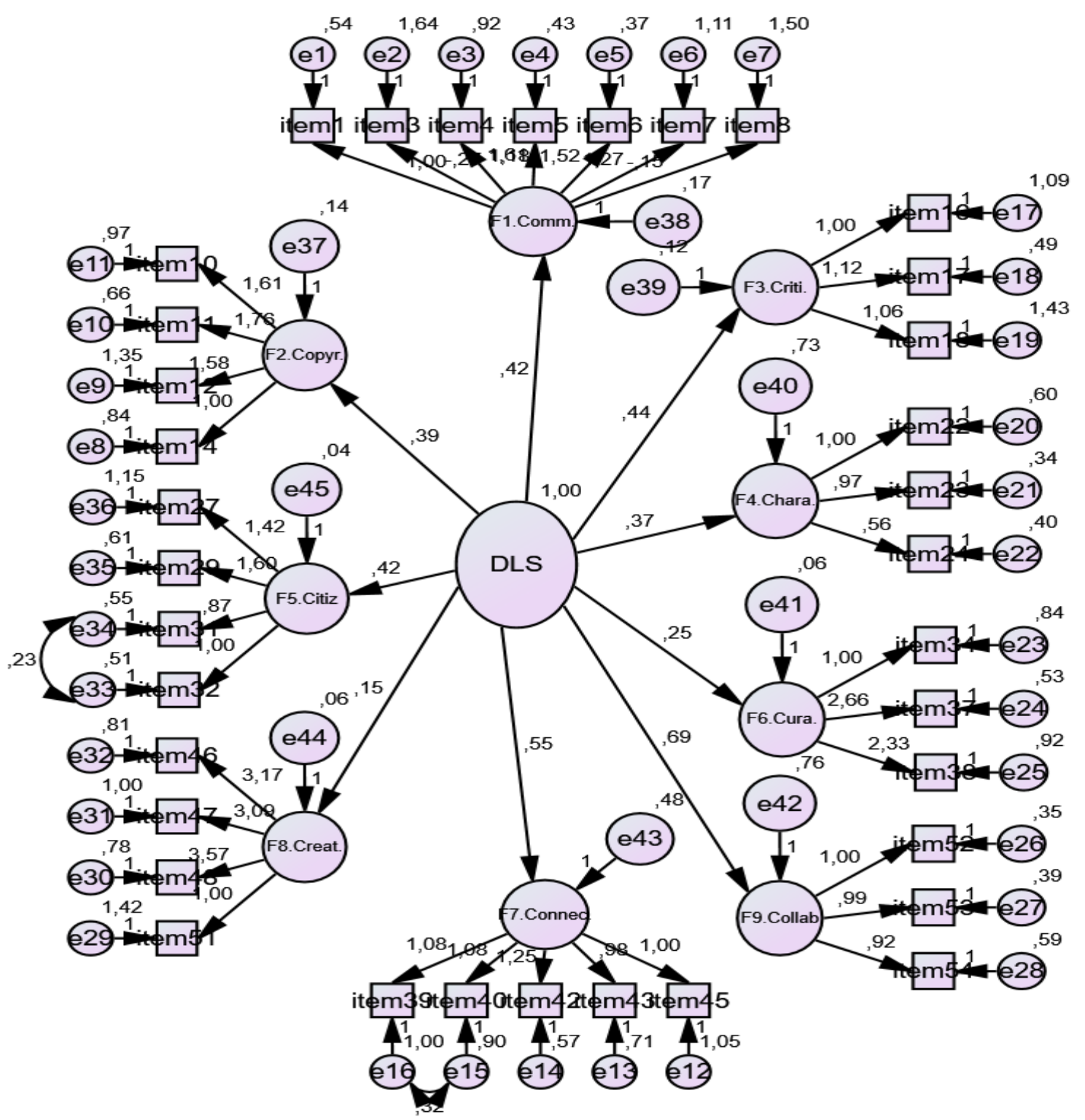

The result shows that all the values i.e. CMIN (minimum value of discrepancy) X2 value is 2.54 at p 0.000, RMSEA (root mean square error of approximation) 0.067, TLI (Tucker Lewis index) 0.939, CFI (comparative fit index) 0.948, and GFI (goodness of fit) 0.924 lies in the acceptable range. Thus, the value of EFA and CFA confirm and validate the structure of DLS.

\subsection{Step 3: Dimensionality and Construct Validity (CFA)}

Sample II yielded 442 responses from university students. Majority of the respondents $(55.5 \%)$ were male. The largest age group (35.5\%) was 21-24 years old. Most of them (24.9\%) 
said to be using the internet for more than thirty-five hours a week. $77 \%$ of them stated that they learned to operate a computer by their personal efforts.

Cronbach's alpha was applied again to see the reliability of this scale. The results show that each dimension has a score higher than 0.7 which is an acceptable value. Value for communication is 0.89 ; copyright 0.86 ; critical thinking 0.82 ; character 0.87 ; citizenship 0.80 ; curation 0.74 ; connectedness 0.76 ; creativity 0.82 and collaboration 0.78 . Overall, DLS has 0.90 Cronbach's alpha value, which shows that the reliability of the scale is quite high. Again, AMOS program was used to confirm the factor structure of DLS scale for the second sample. Figure iv presents the results of CFA.

Figure iv: Result of CFA (Sample 2)

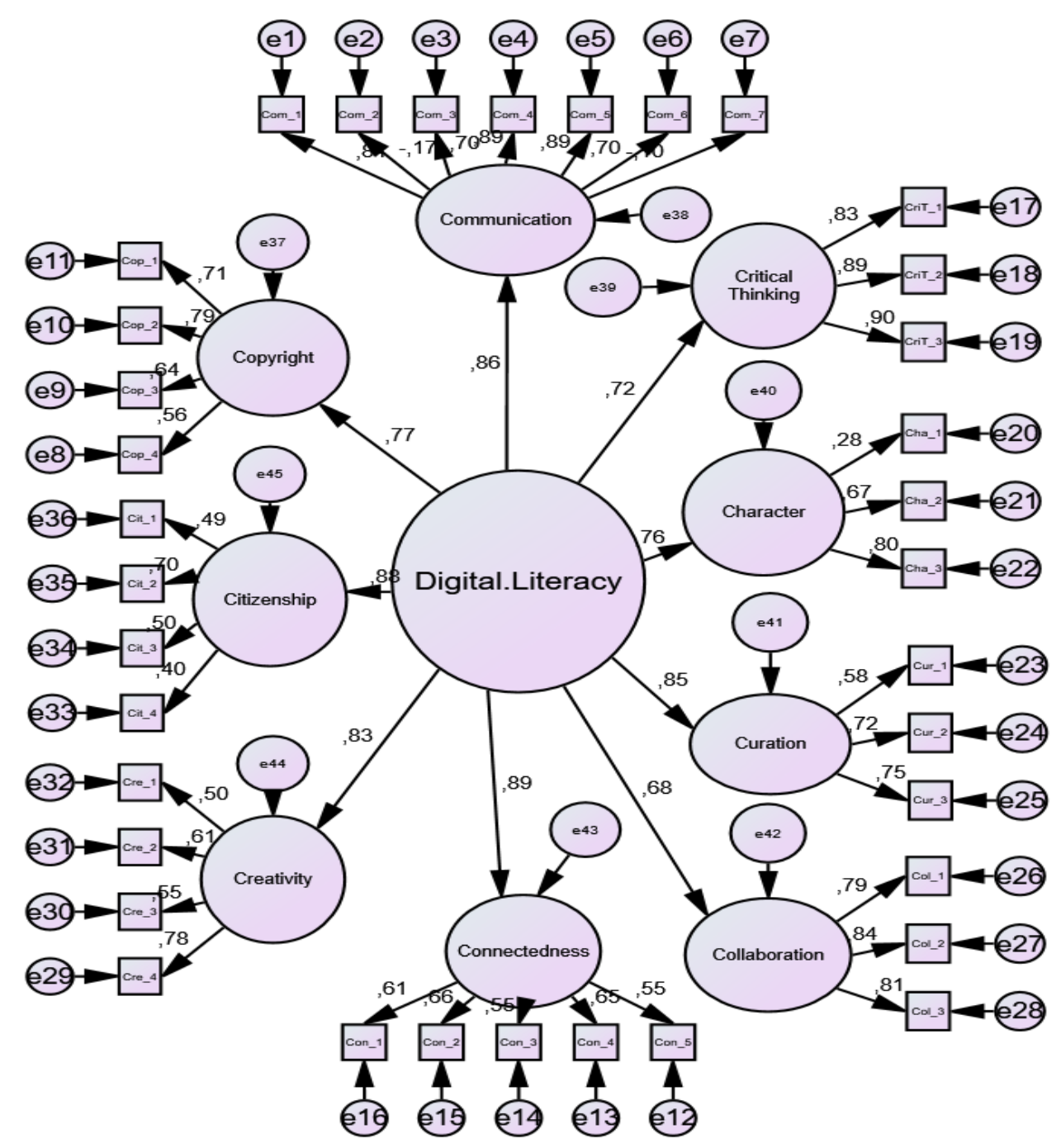


As a result of the confirmatory factor analysis performed with the data obtained from the second sample, it was revealed that standardized estimated values are positive and the goodness of fit values are among the acceptable range (Schermelleh-Engel et al., 2003). Furthermore, value for CMIN $\left(\chi^{2}\right)$ is 2.26; p 0.000; RMSEA 0.052; CFI 0.948; TLI 0.928; and GFI is 0.922.

As a result of this last process, the standardized Digital Literacy Scale (DLS) has 9 factors (dimensions) and 36 items on a Likert-type scale. The factor structure of the DLS and the final version of the items are listed in Annex-i.

\section{Discussion}

This research aimed at developing and validating of Digital Literacy Scale (DLS) with sound psychometric properties that could be used to measure digital literacy based on Chen's (2015) 9 C's. Although it can be used generally as well, it is specially developed for the students in higher education institutions. Findings of this study revealed that DLS proposed with 9 factors is a comprehensive tool to measure the perception of one's digital literacy skills at the tertiary education level.

When compared to digital literacy scales developed earlier, it is theoretically more sound and comprehensive. Most of the earlier scales about digital literacy focused on communication, functionality, and managing information (Abbas et al., 2019; Martzoukou, et al., 2020). Based on the 9 C's of Chen (2015), this scale not only covers the essential digital functional skills; but also focuses on its social, psychological, moral, and ethical aspects.

This study confirms that digital literacy is a multi-dimensional construct and requires a comprehensive theoretical background that should include all major elements of digital literacy that one should possess to thrive in the digital world. The factors of DLS are not only in line with the models presented by Eshet-Alkalai (2004); Martin (2006); Badwen (2008); Ng (2012) and Inskip (2014); but based on 9 C's, is further expansion. The final scale has 36 items that were proved to be reliable after EFA and CFA analysis. DLS may not only be used as a valid and reliable scale to measure the digital literacy skills of the higher education students, but also to the general population.

\section{Practical Implications and Future Research}

Statistics of Pakistan regarding digitalization and digital literacy highlighted the current ranking of Pakistan in South Asia. Even compared to India, Iran, Sri Lanka, and Bangladesh; the ranking of Pakistan on the digital literacy environment indicator is quite low (Khan et al., 2018). It indicates that higher education institutions and the overall education system of Pakistan have yet not caught up with the agenda of digital competencies as a core and fundamental literacy for the forthcoming era. This is indeed alarming and disturbing especially after looking at the post covid-19 context around the globe. The sudden paradigm shift in the teaching-learning process requires the students and graduates to be equipped with digital skills to cope with the complexities of the job market. Thus, it demands from universities to assess and develop the digital literacy skills of students and make digital literacy part of core subjects in the curricula of undergraduate and graduate degree programs. The current scale can play a significant role in this regard as it may help to understand the current situation so that relevant policies and practices may be developed to improve the digital literacy of our digital generation. This scale may further 
be used to find the relationship of students' digital literacy with their academic performance, communication, and research skills.

This scale may be validated further by using a sample from different levels and countries. Literature shows that such scales should be tested and revised after a certain period of time. It is even more important in an area like digital literacy which is continuously evolving due to technological innovations. The convergent validity may also be determined by using similar scales which theoretically correlate and serve the same purpose.

\section{References}

Abbas, Q., Hussain, S., \& Rasool, S. (2019). Digital Literacy Effect on the Academic Performance of Students at Higher Education Level in Pakistan. Global Social Sciences Review, 4(1), 154-165.

Adeoye, A. A. \& Adeoye, B. J. (2017). Digital Literacy Skills of Undergraduate Students in Nigeria Universities. Library Philosophy and Practice (ejournal), 1665.

American Library Association. (2012). Digital Literacy, Libraries, and Public Policy: Report of the American Library Association Digital Literacy Task Force. ALA, Chicago.

Amin, H., \& Mirza, M. S. (2020). Comparative study of knowledge and use of Bloom's digital taxonomy by teachers and students in virtual and conventional universities. Asian Association of Open Universities Journal, 15(2), 223-238.

Bawden, D. (2008). Origins and concepts of digital literacy. Digital literacies: Concepts, policies and practices, 30, 17-32.

Bryman, A. \& Cramer, D. (2001). Quantitative analysis with SPSS release 10 for windows: a guide for social scientists. London and New York: Routledge.

Burnett, C. \& Merchant, G. (2011). Is there a space for critical literacy in the context of new media? English, Practice and Critique, 10(1), 41-57.

Büyüköztürk, Ş. (2009). Sosyal Bilimler İçin Veri Analizi El Kitab1 (Onuncu Baskı). (Data Analysis Handbook for Social Sciences - $10^{\text {th }}$ Ed.), Ankara: Pegem Akademi.

Çam, E. \& Kiyici, M. (2017). Perceptions of Prospective Teachers on Digital Literacy. Malaysian Online Journal of Educational Technology, 5(4), 29-44.

Chan, B. S., Churchill, D., \& Chiu, T. K. (2017). Digital literacy learning in higher education through digital storytelling approach. Journal of International Education Research, 13(1), 1-16.

Chen, A. (2015). The 9 C's of Digital Literacy. Alice in Wonder Tech. http://wondertechedu.blogspot.com/2015/02/the-9-cs-of-digital-literacy.html

Comrey, A. L. \& Lee, H. B. (2013). A first course in factor analysis. Psychology Press. New Jersey: Erlbaum.

CourseSmart. (2011). Digital dependence of today's college students revealed in new study from CourseSmart ${ }^{\mathrm{TM}}$. http://www.prnewswire.com/news-releases/digital-dependence-oftodays-college-studentsrevealed-in-new-study-from-coursesmart-122935548.html 
Croasmun, J. T. \& Ostrom, L. (2011). Using Likert-Type Scales in the Social Sciences. Journal of Adult Education, 40(1), 19-22.

DeVellis, R. F. (2012). Scale development: Theory and applications ( ${ }^{\text {rd }}$ ed.), Washington, DC: SAGE Publications.

Eshet-Alkalai, Y. (2004). Digital literacy: A conceptual framework for survival skills in the digital era. Journal of educational multimedia and hypermedia, 13(1), 93-106.

Gee, J. P. (2003). What video games have to teach as about learning and literacy? ( $1^{\text {st }}$ ed.). Palgrave Macmillan.

Gillen, J. \& Barton, D. (2009). Digital literacies: a discussion document for the TLRP-TEL (Teaching and Learning Research Programme-Technology Enhanced Learning) workshop on digital literacies.

Gilster, P. (1997). Digital literacy ( $1^{\text {st }}$ ed.). Wiley \& Sons, Inc.

Greene, J. A., Yu, S. B., \& Copeland, D. Z. (2014). Measuring Critical Components of Digital Literacy and their Relationships with Learning, Computers \& Education, 76, 55-69.

Gruszczynska, A., Merchant, G., \& Pountney, R. (2013). " Digital Futures in Teacher Education": Exploring Open Approaches towards Digital Literacy. Electronic Journal of e-Learning, 11(3), 193-206.

Hair, J. F., Black, W. C., Babin, B. J., Anderson, R. E., \& Tatham, R. L. (2006). Multivariate Data Analysis, Dorling Knidersley.

Henderson, M., Selwyn, N., Finger, G., \& Aston, R. (2015). Students' everyday engagement with digital technology in university: exploring patterns of use and 'usefulness'. Journal of Higher Education Policy and Management, 37(3), 308-319.

Hinkin, T. R. (1998). A brief tutorial on the development of measures for use in survey questionnaires. Organizational research methods, 1(1), 104-121. https://doi.org/10.1177/109442819800100106

Hinkin, T. R. \& Tracey, J. B. (1999). An analysis of variance approach to content validation. Organizational Research Methods, 2(2), 175-186. https://doi.org/10.1177/109442819922004

Inskip, C. (2014). Mapping resources to competencies: a quick guide to the JISC Developing Digital Literacies resources.

JISC. (2010). What are Open Educational Resources? [online]. https://www.jisc.ac.uk/fullguide/open-educational-resources

Kaiser, H. F. (1974). An index of factorial simplicity. Psychometrika, 39(1), 31-36.

Khan, M. Y. \& Mahar, A. K. S. G. Y. (2018). New Technologies and Digital Literacy in Education: A Shifting Paradigm. Pakistan Social Sciences Review, 2(1), 108-118.

Kim, M. \& Choi, D. (2018). Development of youth digital citizenship scale and implication for educational setting. Journal of Educational Technology \& Society, 21(1), 155-171.

Kress, G. R. (2003). Literacy in the new media age. London: Routledge. 
Kuhlemeier, H. \& Hemker, B. (2007). The impact of computer use at home on students' Internet skills. Computers \& Education, 49(2), 460-480. https://doi.org/10.1016/j.compedu.2005.10.004

Lau, W. W. \& Yuen, A. H. (2014). Developing and validating of a perceived ICT literacy scale for junior secondary school students: Pedagogical and educational contributions. Computers \& Education, 78, $1-9$. https://doi.org/10.1016/j.compedu.2014.04.016

Literat, I. \& Glaveanu, V. P. (2018). Distributed creativity on the internet: A theoretical foundation for online creative participation. International Journal of Communication, 12, 16.

Martin, A. (2006). A European framework for digital literacy. Nordic Journal of Digital Literacy, 1(02), 151-161.

Martin, A. (2008). Digital Literacy and the "Digital Society". In C. Lankshear \& M. Knobel (Eds.), Digital Literacies: Concepts, Policies and Practices (pp. 151-176). New York: Peter Lang.

Martzoukou, K., Fulton, C., Kostagiolas, P., \& Lavranos, C. (2020). A study of higher education students' self-perceived digital competences for learning and everyday life online participation, Journal of Documentation, 76(6), 1413-1458.

Ng, W. (2012). Can We Teach Digital Natives Digital Literacy? Computers \& Education, 59, 1065-1078.

Nordin, M. S., Ahmad, T. B. T., Zubairi, A. M., Ismail, N. A. H., Rahman, A. H. A., Trayek, F. A., \& Ibrahim, M. B. (2016). Psychometric properties of a digital citizenship questionnaire. International Education Studies, 9(3), 71-80.

Noreen, S. \& Malik, M. A. (2020). Digital Technologies for Learning at Allama Iqbal Open University (AIOU): Investigating Needs and Challenges, Open Praxis, 12(1), 39-49. https://doi.org/10.5944/openpraxis.12.1.1016

Nunnally, J. C. \& Bernstein, I. (1994), Psychometric Theory, ( $3^{\text {rd }}$ ed.). McGraw Hill, New York, NY.

Schermelleh-Engel, K., Moosbrugger, H., \& Müller, H. (2003). Evaluating the fit of structural equation models: Tests of significance and descriptive goodness-of-fit measures. Methods of psychological research online, 8(2), 23-74.

Sharma, S. (1996). Applied Multivariate Techniques, New York, John Willey \& Sons. Inc.

Spires, H. A., Paul, C. M., \& Kerkhoff, S. N. (2019). Digital literacy for the $21^{\text {st }}$ century. In Advanced Methodologies and Technologies in Library Science, Information Management, and Scholarly Inquiry (pp. 12-21). IGI Global.

Spires, H. \& Bartlett, M. (2012). Digital literacies and learning: Designing a path forward. Friday Institute White Paper Series.

Spires, H. \& Estes, T. (2002). Reading in web based learning environments. In C. Collins Block 
Sweaney, A. L., Manley, K. S., Meeks, C. B., \& Valente, J. S. (2001). Computer Experience and Skills of Family and Consumer Sciences Undergraduates and Professionals. Education 121(4), 773-780. New York: Guilford Press.

Tang, C. M. \& Chaw, L. Y. (2016). Digital Literacy: A Prerequisite for Effective Learning in a Blended Learning Environment? Electronic Journal of E-learning, 14(1), 54-65.

van Deursen, A. J., van Dijk, J. A., \& Peters, O. (2012). Proposing a survey instrument for measuring operational, formal, information, and strategic internet skills. International Journal of Human-Computer

https://doi.org/10.1080/10447318.2012.670086 


\section{Appendix i: Final DLS -Digital Literacy Scale (Validated and Standardized)}

\begin{tabular}{|c|c|c|c|c|c|c|c|}
\hline \multicolumn{8}{|c|}{ Digital Literacy Scale } \\
\hline Dimensions & $\begin{array}{l}\text { Item } \\
\text { No. }\end{array}$ & Questions & $\begin{array}{l}\text { Strongly } \\
\text { Disagree }\end{array}$ & Disagree & Undecided & Agree & $\begin{array}{l}\text { Strongly } \\
\text { Agree }\end{array}$ \\
\hline \multirow{7}{*}{ 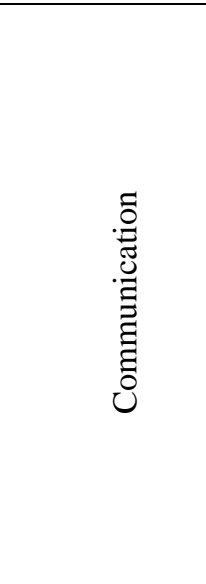 } & 1. & $\begin{array}{l}\text { I can easily read online contents from } \\
\text { screen }\end{array}$ & & & & & \\
\hline & 2. & $\begin{array}{l}\text { I prefer to take prints of online reading } \\
\text { materials for better reading. }\end{array}$ & & & & & \\
\hline & 3. & I can type quickly using both hands. & & & & & \\
\hline & 4. & I know how to write formal emails. & & & & & \\
\hline & 5. & $\begin{array}{l}\text { I am well-aware about email sending and } \\
\text { formatting options. }\end{array}$ & & & & & \\
\hline & 6. & I interact through online audio-video call. & & & & & \\
\hline & 7. & $\begin{array}{l}\text { Online listening through headphone and } \\
\text { speakers is troublesome for me. }\end{array}$ & & & & & \\
\hline \multirow{4}{*}{ 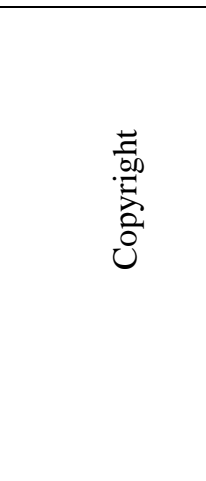 } & 8. & $\begin{array}{l}\text { I know online plagiarism policy of my } \\
\text { institute. }\end{array}$ & & & & & \\
\hline & 9. & $\begin{array}{l}\text { I know the consequences of using } \\
\text { copyright work online without } \\
\text { permission. }\end{array}$ & & & & & \\
\hline & 10 . & $\begin{array}{l}\text { I give acknowledgement/reference in my } \\
\text { online work while using collusion } \\
\text { (copying from fellow students). }\end{array}$ & & & & & \\
\hline & 11. & $\begin{array}{l}\text { I use Turnitin or other similar software to } \\
\text { check and avoid unintentional plagiarism. }\end{array}$ & & & & & \\
\hline \multirow{3}{*}{ 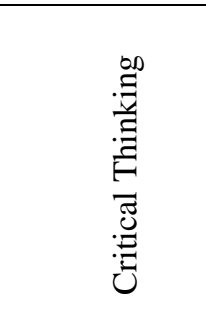 } & 12. & $\begin{array}{l}\text { My university assigns me online activities } \\
\text { relating to real life problems. }\end{array}$ & & & & & \\
\hline & 13. & $\begin{array}{l}\text { I am able to find different pieces of } \\
\text { information online, and put them together } \\
\text { to solve a problem. }\end{array}$ & & & & & \\
\hline & 14. & $\begin{array}{l}\text { I have an online reflective journal to } \\
\text { write. }\end{array}$ & & & & & \\
\hline \multirow{3}{*}{ 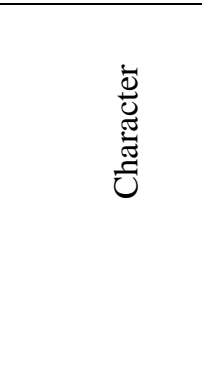 } & 15. & $\begin{array}{l}\text { In online world, I do not use and share } \\
\text { others' personal information, pictures, } \\
\text { conversation etc. without their consent. }\end{array}$ & & & & & \\
\hline & 16. & $\begin{array}{c}\text { I avoid posting negative online comments } \\
\text { and poking in others' discussion and } \\
\text { chatting. }\end{array}$ & & & & & \\
\hline & 17. & $\begin{array}{l}\text { I remain neutral and tolerant during } \\
\text { online discussions. }\end{array}$ & & & & & \\
\hline \multirow[b]{2}{*}{$n=-2$} & 18. & $\begin{array}{l}\text { I communicate with others in a } \\
\text { respectable way while using technology. }\end{array}$ & & & & & \\
\hline & 19. & I know the consequences for violating & & & & & \\
\hline
\end{tabular}




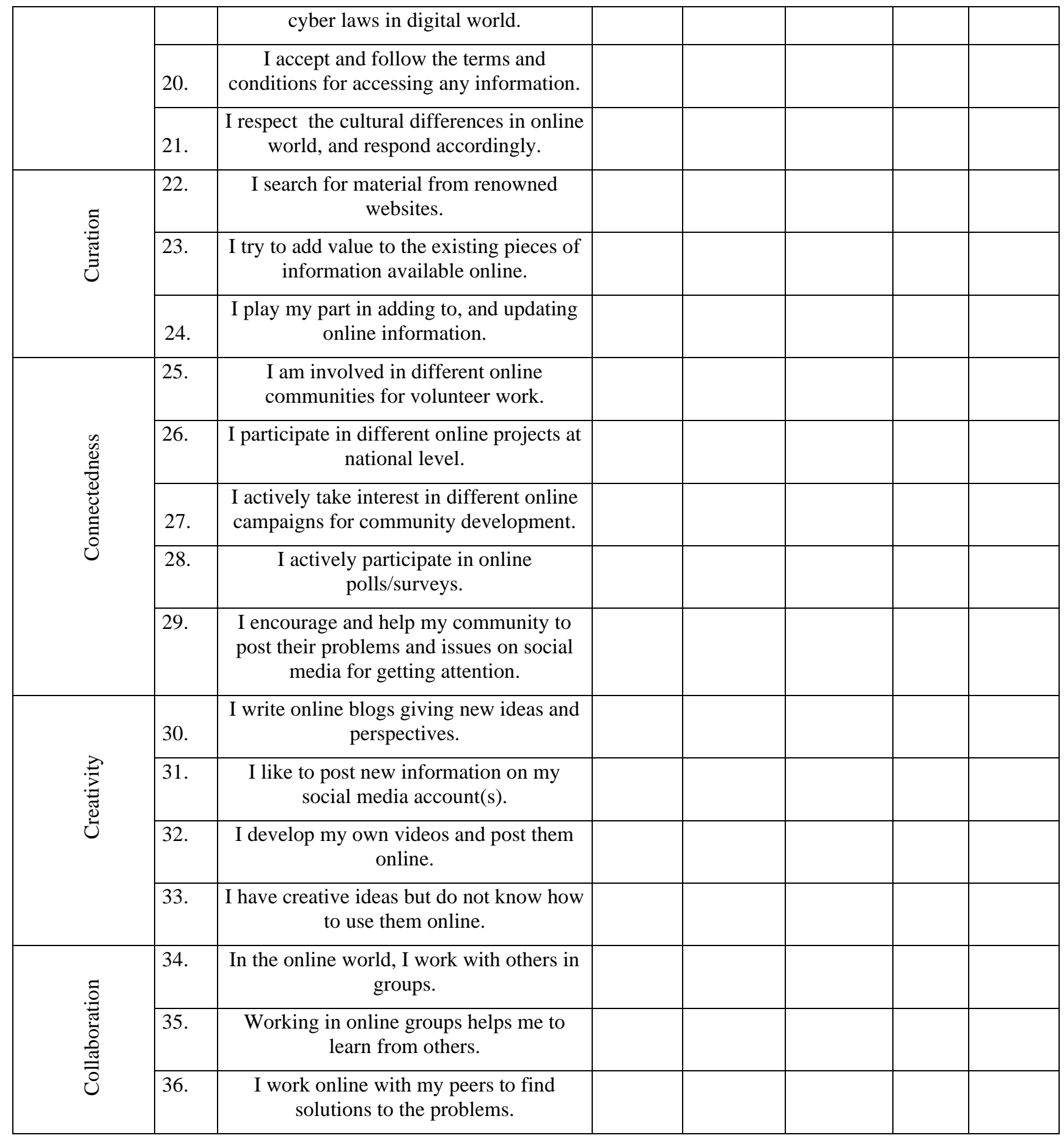

